\title{
The Gurudharmas in Taiwanese Buddhist Nunneries
}

\author{
ANN HEIRMAN AND TZU-LUNG CHIU
}

\author{
UNIVERSITY OF GHENT \\ Ann.Heirman@UGent.be and Tzulung.Chiu@UGent.be
}

\begin{abstract}
According to tradition, Mahāprajāpatī, the Buddha's aunt and stepmother, when allowed to join the Buddhist monastic community, accepted eight 'fundamental rules' (gurudharmas) that made the nuns' order dependent upon the monks' order. This story has given rise to much debate, in the past as well as in the present. This article first shows how the eight rules became an integrated part of the vinaya (disciplinary texts), and more particularly of the Dharmaguptakavinaya, that forms the basis of monastic ordinations in East Asia. Against the background of a much debated attack on these gurudharmas by the Taiwanese nun Shih Chao-hwei, we have then analysed the viewpoints of contemporary Taiwanese nuns, focusing on some less studied, yet very influential, Taiwanese monastic institutes. This research has brought to light a diversity of opinions on the applicability of the rules, relying in each case on a clear vision on Buddhism and vinaya.
\end{abstract}

\section{Keywords}

Taiwanese nuns, gurudharma, vinaya, gender, Dharma Drum Mountain, Nanlin Nunnery, Luminary Nunnery

\section{INTRODUCTION}

According to tradition, the first nun ever ordained was the Buddha's stepmother, Mahāprajāpatī. ${ }^{1}$ Her story appears in the vinayas (Buddhist disciplinary texts), as well as in some other early Buddhist scriptures. ${ }^{2}$ According to the version

1. On this tradition, see, in particular, Harvey 2000, 385-391 and Anālayo 2008, 108-110 (who convincingly criticizes Liz Williams' claim (Williams 2000) that there is textual evidence to support the idea that there may have been a community of nuns before Mahāprajāpatī asked the Buddha for full ordination).

2. For a comparison of vinaya texts, see Sponberg 1992, 13-18; Hüsken 1993, 151-165; Heirman 
most often referred to, when Mahāprajāpatī went to see the Buddha asking for the full ordination, at first her request was not granted, although the Buddha later answered affirmatively to the monk Ānanda's question on whether or not women can become arhats and thus obtain enlightenment. ${ }^{3}$ Also, the fact that Mahāprajāpatī was the Buddha's stepmother played a significant role, and extensive reference is made to the debt the Buddha is said to have owed to his stepmother for everything she has done on his behalf. ${ }^{4}$ Furthermore, Mahāprajāpatī and many other women of the Śâkya clan followed the Buddha for quite some time before they were allowed to enter the Buddhist community as fully ordained nuns. During that time, they were, in fact, away from home, dressed in monastic robes, and they had their heads shaved, which suggests, as recently argued by Anālayo (2011, 289-293), that a semi-monastic life was implicitly allowed by the Buddha. Through further mediation of Ānanda, the Buddha finally permitted women to enter the Buddhist monastic community, providing that they accepted eight fundamental rules (gurudharmas), which make the nuns' order (bhikșunisamgha) institutionally dependent upon the monks' order (bhikșusamgha). These gurudharmas have attracted considerable attention among Buddhist followers and scholars alike. Numerous studies have been made, particularly on the complex issue of the authenticity of the story, and it has been argued by many that the rules were compiled after the nuns' order had been in existence for some time..$^{5}$ Another topic often focused upon is their potential gender discrimination against nuns. ${ }^{6}$

Right up to the present day, the eight fundamental rules have continued to play a role in the relationship between the communities of nuns and monks. This is also the case in Taiwan, the focus of the present article. In the Taiwanese context, one incident has particularly heated the debate. In 2001, on 31 March, during the opening ceremony of the second conference on 'Theory and Practice of Venerable Yin-Shun's Teachings', held by the Buddhist Hongshi Institute, the founder of this institute, the Taiwanese nun Shih Chao-hwei 釋 昭 慧7, publicly announced the abolition of the eight rules, tearing up pieces of paper on which the

2001, 278-284. For an overview of all early accounts of the founding of the order of nuns, see, most recently, Anālayo 2011, 268-272.

3. In most texts, the traditional story on Mahāprajāpatī's ordination is relatively similar, although the Mahāsāṃhika version shows some notable differences (for details, see Heirman 2001, 278-284). Still, texts sometimes differ in regard to what exactly persuaded the Buddha to accept women into the order, and, as discussed in detail in Anālayo 2011, particularly 293-299, to judge from some accounts women's spiritual potential was not what changed the Buddha's mind.

4. These aspects of Mahāprajāpatī's story have been researched in detail by Reiko Ohnuma (2006). As shown by Ohnuma $(2006,871)$, the 'debt to the mother' needed to be repaid, and this repayment was often explicitly linked to the establishment of a nuns' order.

5. For a discussion, see, among others, Horner 1930, 118-161; Hirakawa 1982, 37; Nolot 1991, 397-405; Hüsken 1993, 154-165; Heirman 1997, 34-43; Hüsken 1997, 345-360; Heirman 1998; Chung In Young 1999, 87-88; Kusuma 2000, 8-9; Heirman 2002, Part I, 63-65; Chung, 2006. The compilers of the narrative thus played a crucial role in how the coming into being of a nuns' order was recorded (see Salgado 2008, 187-190).

6. See, among others, Horner 1930, 121; Gross 1993, 36-38; Owen 1998, 9; Dewaraja 1999, 72-74.

7. As a rule, most books and articles today use the pinyin system to transcribe Chinese names and terms. We have done the same throughout this article. Still, when referring to Taiwanese authors, we have opted to use their personal romanization, as they appear on their websites, books or articles. 
eight rules were individually written, one by one. ${ }^{8}$ Since then, discussions have never stopped, and different opinions have been voiced. Generally, as shown by Elise Anne DeVido (2010, 108), three attitudes towards the eight fundamental rules currently co-exist in Taiwanese Buddhist communities:

The first, laissez-faire - neither abolish them nor force nuns to observe them; the second - strict observance of the Rules, including those pertaining to the rainyseason retreat; the third and most recent - to advocate for the Rules' abolishment.

In the present study, we want to investigate what these attitudes imply exactly, focusing, on the basis of intensive fieldwork, ${ }^{9}$ on Taiwanese nuns' perspectives on how to deal with the rules in daily monastic life, taking essential differences between nunneries into account. We thus hope to offer a detailed and balanced view of today's interpretation and implementation of the gurudharmas in Taiwanese nunneries. It is important to note here, just as Wei-Yi Cheng (2007, 85 ) has done, that Buddhist monastics and scholars often have different concerns with regard to the eight fundamental rules: while the former mostly discuss the 'applicability' of the gurudharmas in religious life, the latter might often be more concerned with 'ideological implications'. In this study, we intend to analyse the (practical) impact and meaning of the gurudharmas from the perspective of the Buddhist renouncers, with a focus on significant differences in interpretation and practice in contemporary monastic institutions in Taiwan.

When discussing gender issues in Taiwanese Buddhism, it is important to first consider Foguangshan, the internationally best known Taiwanese monastic institution. When Chao-hwei launched her movement to abolish the eight rules, Foguangshan's founder, Master Hsing Yun, publicly expressed his support in the media. ${ }^{10}$ In Zhongguo shibao 中國時報 (China Times, 1 April 2001), he further stated that, since times have changed, for a long time Foguangshan has 'frozen' the gurudharmas and has implemented a system of gender equality (see Su 2001). Foguangshan is very sensitive to gender issues, and also engages in the international nuns' (bhikșuni) movement (see Cheng 2007, 49). Its views on, and practice of, the gurudharmas have been thoroughly investigated by numerous researchers, showing how at Foguangshan the eight rules can indeed be qualified as 'frozen', without having been officially abolished. ${ }^{11}$ This is confirmed by David Schak's interview data, in which a nun says:

8. Yin Shun 印順 (1906-2005) was a well-known Chinese monk famous for having promoted 'Humanistic Buddhism' in Taiwan.

9. The fieldwork has been supported by the Research Foundation Flanders (FWO), as part of a project on contemporary vinaya practices in Mainland China and Taiwan. In 2010, Tzu-Lung Chiu visited seven nunneries in Mainland China and conducted interviews with 20 senior Chinese nuns. An in-depth discussion of Mainland Chinese nuns' views on the gurudharmas is beyond the scope of this article and will be discussed in a forthcoming Ph.D. dissertation.

10. In 2001, Chao-hwei submitted an article to Ziyou shibao 自由時報 (Liberty Times, 9 September 2001) in appreciation of Master Hsing Yun's support of her protests and activities:

http://www.libertytimes.com.tw/2001/new/sep/9/today-01.htm\#07 (last access 14 June 2012).

In a book of 2010 (26-30), Shih Hsing Yun again expresses his respect for Chao-hwei's work, emphasizing the problems caused by gender inequality and the eight fundamental rules. See also Goodwin 2012, 204.

11. Lin 2001, 254-255; Li 2005, 120-121; Laliberté 2004, 84. Shih Hsing Yun comments that it is 
No one bows down to anyone else here. That just isn't the way things are done. The Master has addressed this before .... In our studies, we see the egalitarianism of the Buddha. We don't go into this much because the question of discrimination against women doesn't arise. There are no Eight Strict Rules here .... . (Schak 2006, 157)

However, Taiwan also has a rich monastic scene beyond Foguangshan monastery, which is much less studied. It is to this scene that we will now turn our attention in order to broaden the scope of research on the concept of gurudharma in Taiwan. The three monasteries chosen as research sites are Fagushan 法鼓 山 (Dharma Drum Mountain), Nanlin Nisengyuan 南林尼僧苑 (Nanlin Nunnery) and Xiangguang Si 香光寺 (Luminary Nunnery). All three institutions play a leading role in the Taiwanese monastic scene, especially for female monastics. While Fagushan has both male and female residents, Nanlin Nisengyuan and Xiangguang Si are for nuns only. Each of the three monastic institutions has particular and representative characteristics regarding vinaya study. Master Sheng Yen (1930-2009), the founder of Fagushan, was regarded as one of Taiwan's most eminent vinaya teachers; Master Wu Yin, the abbess of Luminary Nunnery, is well known for her vinaya research aiming at female monastics; and Nanlin Nunnery is famous in Taiwan for adhering strictly to the traditional vinaya rules.

This article is divided into three parts. The first part introduces the gurudharmas and investigates to what extent they are integrated in the Dharmaguptakavinaya, the vinaya actively used for ordinations in Taiwan. Secondly, Chao-hwei's actions and especially their impact on the monastic scene are discussed. And, finally, in the third and main part of the article, we discuss, based on an analysis of our fieldwork findings, the nuns' perceptions on the applicability of the eight fundamental rules in a Taiwanese context.

\section{THE EIGHT GURUDHARMA RULES}

Generally speaking, the gurudharma rules, as they have been recorded in the extant vinayas, do not differ much among the various traditions, although the order can be relatively variable. ${ }^{12}$ They are enumerated below, following the Dharmaguptakavinaya (T 1428 923a26-b21). Most of the eight fundamental rules correspond to a parallel rule in the bhikșuniprātimokșa (list of rules for nuns, further commented upon in the bhikșunivibhanga, vinaya chapter for nuns): ${ }^{13}$

1) Even when a nun has been ordained for one hundred years, she must rise up from her seat when seeing a newly ordained monk, and she must pay obeisance and offer him a place to sit.

The same rule, with nearly the same words, can also be found in the Dharmaguptaka bhikșunìvibhanga. Pācittika (hereafter pāc.) $)^{14} 175$ states:

If a nun of one hundred years sees a newly ordained monk, she must rise, meet him, pay obeisance to him, greet him respectfully, inquire after his health and

unnecessarily painstaking to abolish the rules, and advocates that they should be dropped gradually (Yuan, Lianhe bao 聯合報 (United Daily News), 21 April 2002).

12. For an overview, see Chung Jin-il 1999, 229.

13. For a discussion, see also Wu Yin 2001, 81-83.

14. Pācittika, Pāli pācittiya and variants: an offence that needs to be expiated (cf. Heirman 2002, Part I, 141-147). 
offer him sitting material. If she does not do so, she [commits], except in particular circumstances, a pācittika. ${ }^{15}$

As further explained in the Dharmaguptakavinaya (T 1428 777a10-11), these "particular circumstances' occur when a nun has been offered food by a layman. In that case, she must not rise when she is following some special ascetic rules (toutuo 頭陀, dhūta), ${ }^{16}$ when she is sick or when there is enough food for all.

Some vinayas describe how Mahāprajāpatī tried to change this rule, asking that nuns could be greeted according to seniority. ${ }^{17}$ This request is denied for two main reasons: on the one hand, as argued in the Pâli vinaya, in other ascetic groups, men also do not greet women; on the other hand, as underlined in the Mahiśāsakavinaya and in the Mūlasarvāstivādavinaya, women are always (hierarchically) inferior to men, for various reasons. ${ }^{18}$

2) A nun may not revile a monk, saying that he has broken the precepts, [or gone against] right views or right behaviour.

The rule is similar to pācittika rule 145 for nuns of the Dharmaguptakavinaya, which states that a nun should not revile a monk, on pain of committing a pācittika offence. ${ }^{19}$ The vinaya adds that a monk should equally not revile a nun. If he does so, he commits a dușkrta, 'a wrong-doing', a lighter offence. ${ }^{20}$

3) A nun may not punish a monk, nor prevent him from joining in the ceremonies of the order (such as the poșadha $a^{21}$ or the pravāran $\bar{a}^{22}$ ). A nun may not admonish a monk, whereas a monk may admonish a nun.

This rule is quite closely related to the second rule. It does not correspond directly to a Dharmaguptaka prātimokșa rule.

15. T 1428 777a13-15. The Mahīśāsakavinaya, T 1421 97c20-28 (pāc. 178) and the Sarvāstivādavinaya, T 1435 324b29-c20 (pāc. 103) have a similar rule. Related is pāc. 94 of the Pāli vinaya (Vin IV 343-344), that states that a nun should not take a seat in the presence of a monk without asking his permission. The latter rule is also part of the rules for nuns in the Sarvāstivādavinaya, T 1435 324c21-325a6 (pāc. 104). See also Waldschmidt 1926, 118; Hüsken 1997, 346-348; Heirman 2002, Part II, 955-957.

16. On dhūtas, see Dantinne 1991; Heirman 2002, Part II, 298-301, note 142.

17. Pāli vinaya, Vin II 257-258, Mahīsāāakavinaya, T 1421 186a7-28, Mūlasarvāstivādavinaya, T 1451 351c29-352a25.

18. For details, see Heirman 2001, 278-284.

19. T 1428 767a18-b11. Similar rules can be found in the Pāli vinaya (Vin IV 308-309, pāc. 52), the Mahāsämghikavinaya, T 1425 532c26-533a19 (pāc. 91), and the Sarvāstivādavinaya, T 1435 340b17-c19 (pāc. 154). The Mahissāalakavinaya, T 1421 93b15-25 (pāc. 131) has a related rule that states that a nun who tells a layman about an offence of a monk, commits a pācittika offence. See also Waldschmidt 1926, 118-119; Hüsken 1997, 354; Heirman 2002, Part II, 882884 .

20. T 1428 767b7. Mahāsāmghikavinaya, pāc. 91, T 1425 533a16-19, states that a monk should not revile a nun, on pain of a vinayātikrama (a light offence, corresponding to the term duṣkrta in other vinaya traditions, cf. Nolot 1991, 384-386).

21. Twice a month, at the poșadha ceremony, the prātimokșa (list of rules) is recited. In this way, the ceremony serves as a bond between the members of the same vinaya tradition.

22. The pravāranā (or invitation) ceremony is held at the end of the summer retreat. On this occasion, every monk (and nun) is expected to invite his (her) fellow-monks (nuns) to point out his (her) wrongs, if any, whether seen, or heard or suspected. On this ceremony, see, in particular, Chung 1998.

\section{equinoxonline}


4) After a woman has been trained for two years in the six rules as a probationer (śikșamānāa), the ordination ceremony must be carried out in both orders (first in the nuns' order, and then in the monks' order).

A probationer is a status between a novice and a nun, only applicable to women. The training typically starts at the age of $18 .^{23}$ During her two years of study, the probationer particularly has to take into account a certain number of special rules. ${ }^{24}$ At the age of 20, a woman can be ordained as a bhikșuni ${ }^{25}$ This has to be done in both orders. The Dharmaguptakavinaya specifies that a candidate first has to ask for the ordination in the nuns' order and then in the monks' order (pp. 924c7-925b17). As further stated in pācittika 139, both procedures have to be performed on the same day. ${ }^{26}$

5) When a nun has committed a samghāvaśeșa offence, she has to undergo the mānatva in both orders for half a month.

A samghāvaśeșa offence leads to a temporary exclusion from the main activities of the community (see Heirman 2002, Part I, 128-138). If a monk goes against a samghāvaśeșa rule, he has to undergo a period of penance. In a case where he has concealed his offence, he first has to undergo a so-called parivāsa period ('period of residence'), which lasts as long as the time he has concealed his offence, followed by a mannatva period (maybe to be understood as "condition of paying respect'; Edgerton 1985 [1970], 429), which takes six days. During these periods, many restrictions are imposed upon him. In addition, in the mānatva period, a monk daily has to remind the order that he is undergoing a period of penance. After this, a monk can be rehabilitated by the community and re-admitted as a full member. A parivāsa is never inflicted on nuns. Instead, they have to undergo a mānatva period of two weeks. During this period, they are controlled by both orders. According to Ute Hüsken, the reason for the absence of a parivāsa period for nuns, might be of a practical nature. Anyone who undergoes a period of penance may not live together with 'pure' monks or nuns. Possibly, for nuns, this was not feasible (Hüsken 1997, 104-105).

The above rule has led to some discussion, caused by the fact that some vinayas do not explicitly mention the term samghāvaśeșa, but instead refer to a 'severe offence'. ${ }^{27}$ However, a comparison between all vinayas as well as internal evidence

23. For a detailed discussion on the probationer, see, among others, Chung 2006 and Heirman 2008.

24. Pāli vinaya, Vin IV 319; Mahīśāsakavinaya, T 1421 186b16-18; Mahāsāṃghikavinaya, T 1425 471c2-15; Dharmaguptakavinaya, T 1428 924b6-c2; Sarvāstivādavinaya, T 1435 327a7-c2; Mūlasarvāstivādavinaya, T 1443 1005a3-19. For details, see Hirakawa 1982, 53-54, note 17 (stating that the six rules of the Pāli vinaya and of the Dharmaguptakavinaya are probably the oldest ones); Heirman 2000, Part I, 67-75.

25. On the age of a candidate and exceptions allowed for married women, see, among others, Heirman 2002, Part I, 82-88; Kieffer-Pülz 2005; von Hinüber 2008, 3-19 (who shows that, originally, these exceptions were not referring to married women, but rather to women who had been known to the lay community for a certain period of time).

26. T 1428 764b13-c11, similar to Pāli vinaya, Vin IV 335-336 (pāc. 81; for a discussion see Waldschmidt 1926, 144-145; Hüsken 1997, 276-279), Mahiśāsakavinaya, T 1421 92b20-27 (pāc. 11), Mahāsāṃghikavinaya, T 1425 536c24-537a16 (pāc. 107), Sarvāstivādavinaya, T 1435 331a17334c29 (pāc. 127), Mūlasarvāstivādavinaya, T 1443 1008b21-c3 (pāc. 125).

27. Pāli vinaya, Vin II 255; Mahīśāsakavinaya, T 1421 185c26-28; Mūlasarvāstivādavinaya, T 1451

(C) Equinox Publishing Ltd 2012

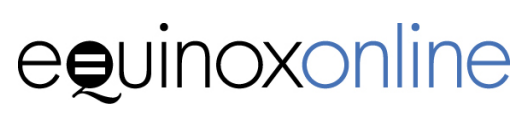


makes it clear that, apart from the Mahāsāmghika tradition, all vinayas state that a mānatva penance has to be imposed upon a nun committing a samghāvaśeșa offence. ${ }^{28}$ This fifth gurudharma does not reappear among the prātimokșa rules for nuns.

6) Every fortnight, nuns have to ask monks for instruction.

This rule is parallel to pācittika 141 of the bhikșunivibhanga of the Dharmaguptakavinaya. ${ }^{29}$ First, a small group of nuns has to go to the monks' order asking for instruction. Thereupon, the monks' order sends a monk to the nuns' order to give instruction. ${ }^{30}$ This latter regulation corresponds to one of the pācittika rules (pāc. 21) for monks. ${ }^{31}$ According to the Dharmaguptakavinaya (T 1428 649a12 ), the instruction concerns the eight fundamental rules. This is also the case in the Mahissāsakavinaya (T 1421 45c7-8) and in the Sarvāstivādavinaya (T 1435 82a3 and 6). ${ }^{32}$ In the Pāli vinaya, nuns should ask both for the date of the poșadha ceremony and for instruction in the eight fundamental rules (Vin IV 52, 315). For the Mahāsämghikavinaya, the instruction concerns the precepts, as well as vinaya in general and abhidharma (T 1425 541c17 and 346a23-24). The Mūlasarvāstivādavinaya (T 1442 798a29-b1), finally, states that the bimonthly instruction concerns the concepts of morality (jie 戒, śila), meditation (ding 定, samādhi) and insight (hui 慧, prajñ $\bar{a})$, the three divisions of the noble eightfold path.

7) Nuns cannot spend the summer retreat (rains retreat, varșā) in a place where there are no monks.

This rule is parallel to pācittika 143 of the bhikșunivibhanga of the Dharmaguptakavinaya. ${ }^{33}$ Given the institutional dependence of the nuns' community upon the monks' community, it is only logical that nuns should stay in the neighbourhood of a monastery where monks live. This was presumably in a city, as clearly shown by Gregory Schopen in an article that, albeit on a seemingly trivial object, the chamber pot, strikingly reveals to what extent nuns were integrated into urban life (Schopen 2008).

8) At the end of the summer retreat, nuns have to carry out the pravāranā ceremony (also) in the monks' order.

351a20-22. The Mahāsāmghikavinaya, T 1425 475a8-13, mentions both jing fa 敬法 ('rule of respect', gurudharma) and samghāvaśeșa.

28. Hüsken 1997, 103-105, 350-352, 356-357; Heirman 1998; Chung Jin-il 1999, 230-231.

29. T $1428765 a 11-c 13$ (pāc. 141), similar to Pāli vinaya, Vin IV 315 (pāc. 59), Mahīśāsakavinaya, T 1421 90a21-b1 (pāc. 100), Mahāsāmghikavinaya, T 1425 541b25-c27 (pāc. 132), Sarvāstivādavinaya, T 1435 339c9-22 (pāc. 151), and Mūlasarvāstivādavinaya, T 1443 1008c4-16 (pāc. 126).

30. For details, see Heirman 1997, 41.

31. T 1428 647b9-649c3, similar to Pāli vinaya, Vin IV 49-53, Mahīśāsakavinaya, T 1421 45a15c10, Mahāsāṃghikavinaya, T 1425 345c23-346a25, Sarvāstivādavinaya, T 1435 80a29-82a6, and Mūlasarvāstivādavinaya, T 1442 792a13-803c23, all pāc. 21.

32. In addition, the Sarvāstivādavinaya (T 1435 345c15-17) has a gurudharma rule saying that nuns must ask monks for instruction in sūtra, vinaya and abhidharma. The third rule of the Dharmaguptakavinaya, saying that a nun may not punish a monk nor prevent him from joining in ceremonies, does not, instead, appear in the Sarvāstivādavinaya.

33. T 1428 766b10-c2, similar to Pāli vinaya, Vin IV 313 (pāc. 56), Mahīśāsakavinaya, T 1421 89a20b9 (pāc. 91), Sarvāstivādavinaya, T 1435 339b7-21 (pāc. 149), and Mūlasarvāstivādavinaya, T 1443 1009a1-14 (pāc. 128).

\section{eevinoxonline}


At the pravāranā ceremony (invitation ceremony) every nun invites her fellow nuns (and, in the second instance, the monks' community) to point out her wrongs, whether seen, heard or suspected..$^{34}$ This rule is parallel to pācittika 142 for nuns of the Dharmaguptakavinaya, where it is explained that, after the procedure in the nuns' community, the nuns have to appoint a delegate to go to the monks' community in order to inquire whether the monks have any remarks concerning an offence that a nun has been seen, heard or suspected of having committed. For her protection, ${ }^{35}$ the delegate nun must take two or three other nuns with her. ${ }^{36}$

As we have seen, most of the eight gurudharma rules are an integral part of the vinaya. Still, responses to them vary widely, depending on time, region and context. In the following parts of the article we focus on how contemporary Taiwanese nuns perceive these rules and their applicability, taking into account the diverse monastic scene of Taiwan.

\section{SHIH CHAO-HWEI}

Any discussion about the gurudharmas in Taiwan should include the highly debated actions of the Buddhist nun Shih Chao-hwei, who was born in Myanmar in 1957, and later moved to Taiwan in 1965. She was ordained as a Buddhist nun in 1980, and in 1988 became a public figure as a Buddhist radical activist, leading various social protests related to various issues such as human rights, animal rights or environmental protection. ${ }^{37}$

In 'Buddhism and Women: Deconstructing Male Chauvinism in Buddhism' (1999), Chao-hwei explains why she wants to take action against the gurudharmas. In her early monastic years, she says, she felt that monastic people should approach everyone without any arrogance. Buddhist nuns could thus even pay homage to cats and dogs, which are regarded as future Buddhas according to the practices of the bodhisattva path. Why then should nuns not bow to monks? However, Chao-hwei later felt that some chauvinistic monks were teaching nuns slavish observance, introducing a strong sense of inferiority (1999, 363-364). In a conference paper of 2007, she further refers to what she calls some 'emperorlike' monks who wrote anonymous articles in the Sengqie Zazhi 僧伽雜誌 (Samgha Magazine). ${ }^{38}$ The articles underline the importance of observing the eight rules, and in doing so they talk of numerous negative female characteristics ${ }^{39}(2007, \mathrm{~B} 7)$. She relates how, in response, she started to write articles and deliver lectures,

34. See note 22 .

35. The seventh samghāvaśeșa rule of the Dharmaguptakavinaya (T 1428 720b16-721a29) mentions that, for her safety, a nun can never travel alone. She runs the risk of being physically attacked. Protection also involves control. As equally stated in the same Dharmaguptakavinaya rule, the community also wanted to make sure that a nun travelling alone does not commit any offence, expecially an offence related to sexual acts.

36. T 1428 765c14-766b9 (pāc. 142), similar to Pāli vinaya, Vin IV 313-314 (pāc. 57), Mahišāasakavinaya, T 1421 89b20-29 (pāc. 93), Sarvāstivādavinaya, T 1435 339b22-c8 (pāc. 150), and Mūlasarvāstivādavinaya, T 1443 1009a15-29 (pāc. 129).

37. For a detailed introduction of Shih Chao-hwei, see DeVido 2010, 102-110.

38. For more details on these articles and Chao-hwei's reaction, see Li 2008, 194-197.

39. Regularly referred to in this context, are the negative views on womanhood uttered in T 1478, Da'aidao biqiuni jing 大愛道比丘尼經 (Sütra on the Bhikșunī Mahāprajāpatī), a text that started 
believing that nuns were being brainwashed, particularly at the ordination ceremony or in some Buddhist colleges where the gurudharmas are strictly observed (both in Taiwan and in Mainland China). ${ }^{40}$

Besides discussing the impact of the eight rules in Chinese Buddhist contexts, Chao-hwei also shows her concern for Buddhist women in Theravāda countries, notably the few bhiksunis in Sri Lanka and the religious women of Southeast Asia, known as maechi ${ }^{41}$ in Thailand and as thilá-shin ${ }^{42}$ in Myanmar $(1999,374)$. She relates how a Taiwanese nun from Luminary Nunnery told her how she felt that maechis show their subservience, when she saw them crawling on their knees to worship monks in Ven. Ajahn Chah's monastery in Thailand. ${ }^{43}$ According to Chaohwei, who uses strong pejorative language, this shows how Theravāda monks represent the bhikșu chauvinism of ancient India. She argues that these monks have not yet fully understood the Buddhist Dharma and are therefore unable to grasp the deep meaning of the equality of all sentient beings $(1999,375)$. Chao-hwei also proposes straightforward ideas on the detailed instructions of the gurudharmas (1999, 357-361). The rules on the rains retreat (7), on seeking instruction (6), on the settlement of a samghāvaśeșa offence (5), and on the ordination (4) and invitation (8) ceremonies, for which the assistance of monks is needed, show, according to Chao-hwei, how at the time of Mahāprajāpatī, the training of new nuns was entrusted to monks, since it was impossible for the Buddha to always stay with the nuns. They do not manifest any privileges. Yet, some chauvinistic monks have abused the gurudharmas to suppress the development of the bhiksunisamgha. She further challenges the authenticity of the rules, underlining that the original eight rules were not, as is the case with other rules, established in response to transgressions made by nuns. ${ }^{44}$ As an example, she gives the

to gain popularity in China from the fifth century onwards (see Li 2000, 149-150 and Heirman 2001, 284-289).

40. Tzu-Lung Chiu's fieldwork data indeed indicate that Chinese nuns in Mainland China are, at the ordination ceremony, educated to practise the gurudharmas. The majority of the Mainland China informant nuns stress the importance of the eight rules, an issue that will be discussed more in-depth in Tzu-Lung Chiu's Ph.D. dissertation.

41. Maechis are religious women who, without being ordained as bhikșunis, live in nunneries. They observe eight or ten Buddhist precepts, shave their heads and wear white-coloured robes. On their role in Thai society, see, among others, a recent article by Martin Seeger (2009).

42. Thilá-shin are religious women, like Thai maechis, who live in nunneries, without being ordained as bhikșunis. They live according to the ten precepts of a novice nun, shave their heads and wear pink robes. On their religious standing in Burmese society, see, among others, Kawanami 1990 and Carbonnel 2009.

43. Similar observations have been interpreted in a different way by other feminist writers. Karma Lekshe Tsomo $(2004,50)$, for instance, notes that bowing at someone's feet is a traditional customary practice in South and Southeast Asia that does not imply a loss of status. Wei-Yi Cheng $(2007,93)$ remarks that the practice of kneeling down to elders or monastics to express respect is common in Sri Lanka, and states that, since in Taiwan it is not a social custom, it may have a heavier hierarchical implication in a Taiwanese context. These remarks fit in well with the very useful comments of Rita Gross, famous for her feminist history of Buddhism (Buddhism after Patriarchy 1993), who in an article on women's studies and gender $(2005,22)$ warns that feminist scholars researching other cultures and religions '[should] be careful not to project [their own] feminist values onto the religious and cultural situations of other times and places'.

44. According to the vinaya, the rules of the prätimokșa have been laid down, one by one, by the 
gurudharma rule (2) saying that nuns should not criticize monks. Relying on the Dharmaguptakavinaya, she points to a story in which Mahāprajāpatī complains to the Buddha about a group of six mischievous monks who acted very badly when they were instructing some nuns. In response, the Buddha scolds the monks and sets up criteria for selecting monk instructors. ${ }^{45}$ According to Chao-hwei, the fact that the Buddha did not admonish Mahāprajāpati for her criticism shows that the above-mentioned gurudharma cannot be authentic.

In conclusion, we can see that Chao-hwei considers the rules, on the one hand, to be quite unreliable, and, on the other hand, to be "products of a historical context' $(1999,361)$. According to her, this enabled some chauvinistic monks to exercise their power unjustly, in the past and in the present, in Taiwan, Mainland China and Southeast Asia. It led her to protest publicly against the gurudharmas on 31 March, 2001, causing a stir in both Buddhist circles and in the media. On that day, the Buddhist Hongshi College, founded by Shih Chao-hwei herself, held the opening ceremony of the second conference on 'Theory and Practice of Venerable Yin-Shun's Teachings'.$^{46}$ Chao-hwei, leading four other monastics (three monks and one nun) and four lay people (two Taiwanese lay scholars, Chen Yishen of Academia Sinica and Jiang Canteng of National Tsing Hua University, and two other lay women, Huang Liming, a board member of a cultural and educational foundation and Li Chunying, editor of Modern Buddhist News), ${ }^{47}$ started a campaign to abolish the gurudharmas, tearing up copies of the eight rules one by one as 'Mahāprajāpatī's Second Revolution'. This movement instantly created 'a full-blown storm of controversy' (DeVido 2010, 107), and reactions varied from very positive to very negative. Jiang Canteng, for instance, one of the most active supporters of Chao-hwei, notes (2003, 259; translated in Shih Chao-hwei 2007, B14-15):

This was the most courageous and innovative movement for Chinese Buddhism within a thousand years. At that moment, it was well recognized by the media in Taiwan's society. Furthermore, the great, rational, and professional pursuits of Taiwan's contemporary bhiksunis for gender equality in Buddhism powerfully forced the Dalai Lama, who was on his second visiting tour in Taiwan, to announce his response (even though not very straightforwardly) at once to this cry for uni-

Buddha each time a monk or a nun is considered to have done something wrong. However, for the gurudharmas this is not the case, since they have been given before the order of nuns had been established. Still, when formulated as prätimokșa rules, they are introduced by a story that explains why they needed to be laid down.

45. T 1428 648a20-c29.

46. Chao-hwei carefully chose good timing in order to attract plenty of attention. On the following day, 1 April, 2001, the Dalai Lama was due to visit Taiwan to give a lecture about 'Moral Perspectives of the New Century'. Prior to the Dalai Lama's arrival in Taiwan, Chao-hwei wrote a newspaper article entitled 'Go for it!, Dalai Lama -When talking about "Moral Perspectives of the New Century”, one might as well learn a classic lesson from Taiwan's Buddhism' (達賴喇嘛加油!一談「新世紀的道德觀」何妨向台灣佛教取經), which was published in Ziyou shibao 自由時報 (Liberty Times) on 28 March, 2001 (online version also on http:// hongshi.org.tw/articleCview.aspx?nono=147 (last access 14 June 2012). It pleaded publicly for the re-establishment of the lineage of Tibetan nuns (bhikșunis), challenging so-called bhikșu (monk) chauvinism.

47. For details, see http://www.hongshi.org.tw/writings.aspx? code=1936AD92B010695A94A75B 5E77FFBB04 (last access 14 June 2012). 
versal human values. Consequently, this movement also had impact upon Taiwan's traditional Buddhist communities and other Asian regions.

Jiang Canteng's note shows how Chao-hwei's action was perceived by her supporters and why it received so much attention in Taiwan: her initiative was seen as a courageous struggle for gender equality, put on a par with universal human values. Thanks to the visit of the Dalai Lama to Taiwan, Chao-hwei attracted extra media attention, thus forcing other monastic communities to respond, which in turn enhanced the impact of her activities. Positive reactions also came from some Taiwanese scholars, such as Li Lingyu, who just as Elise Anne DeVido (2010, 93-110), points to the link between the activities of contemporary Taiwanese nuns and the values of Humanistic Buddhism, while arguing that Chao-hwei's initiative constitutes an important step for the Buddhist feminist movement in Taiwan (Li 2005, 119-141). In a very recent publication, Chiung Hwang Chen deems that Chao-hwei's campaign to abolish the gurudharmas has raised awareness of gender issues in Buddhism and other religions in Taiwan, despite the lack of a general agreement on the movement in Buddhist communities. According to Chen, 'the controversy itself illustrates the power women hold, as Chao-hwei was able to challenge the system, even if not entirely successfully' (Chen 2011, 26). Still, although some people side with Chao-hwei's call, the majority of Buddhist monastics disapprove of her action. Similarly to our fieldwork findings, Wei-Yi Cheng records that most of the nuns she interviewed in Taiwan, regardless of whether or not they accept the gurudharmas, were critical of Chao-hwei's movement, perhaps, according to Cheng, because of her sharp language, also directed to some respected bhikșus (Cheng 2007, 87-88).

As is clear from the above, a consensus on the gurudharmas has not been reached in the Buddhist communities in Taiwan, ${ }^{48}$ still less is there any decision on whether or not to abolish the eight rules. Still, in their every-day practices and teachings, monastic people will often need to deal with questions involving the gurudharmas and their applicabilty. It is to this issue that we now turn our attention, focusing on three research sites: Dharma Drum Mountain, Nanlin Nunnery and Luminary Nunnery.

\section{FIELDWORK RESEARCH AT DHARMA DRUM MOUNTAIN, NANLIN NUNNERY AND LUMINARY NUNNERY ${ }^{49}$}

\section{Dharma Drum Mountain}

Dharma Drum Mountain (Fagushan 法鼓山, abbreviated as DDM) is one of the largest Buddhist institutions in Taiwan, currently with about 50 monks and 200 nuns affiliated to the monastery. It was founded by the monk Sheng Yen 聖嚴 (1930-2009), a prominent Chan master. As is the case in other large monasteries, in DDM the founding master plays a very influential role. This is also the case with regard to the eight fundamental rules. In a discussion on the social position of Taiwanese Buddhist nuns $(2004,223)$, DeVido commented that Master Sheng Yen never emphasized the importance of following the gurudharmas - just as two

48. See also Li 2005, 141; DeVido 2010, 108-109; Chen 2011, 26.

49. All fieldwork data have been collected by Tzu-Lung Chiu in 2009 and 2011.

\section{equinoxonline}


other leading figures of Taiwanese Buddhism, Master Yin Shun印順 (1906-2005) and Master Hsing Yun 星雲 (born in 1927, founding master of Foguangshan monastery), had not. As such, DDM's viewpoint might roughly belong to what DeVido qualifies as a 'laissez-faire' attitude. Still, despite this attitude, the issue remains quite complex and DDM monastic nuns have developed responses to the gurudharmas that are well thought of. A senior DDM nun outlined how the concept of gurudharma is implemented:

In our monastery, neither male nor female monastics have much sense of gurudharma. Master Sheng Yen taught us that bhikșunis need to learn how to be independent rather than to rely too heavily on bhikșus. Bhikșunis can also contribute to Buddhism. In the Buddha's time, there were huge differences between male and female monastics. Here [at Dharma Drum], bhiksunis would not pay homage to a recently ordained monk by kneeling down. Monks in our monastery are very courteous, even the abbot. I feel that the gender equality atmosphere of this monastery is influenced by Taiwanese society. Sometimes I feel that bhikșus are more moderate than bhikșunis, who when choosing to go forth are more independent in their ideas. Master Sheng Yen suggests that there is no gender difference in Chan Buddhism, and that both sexes can contribute to Buddhism.

The nun's statement reveals that monks and nuns in DDM do not pay much attention to the eight rules, basically because of Master Sheng Yen's (Chan) teachings. Equal status is exemplified by nuns not having to kneel down to monks. In daily life monks and nuns all greet each other in the same way, palms joined. A second reason given for gender equality is that Taiwanese society is seen as open to such a position, different from India at the time of the Buddha. So, apart from the founder's teaching, the social context in which the monastery functions is considered to play an important role, allowing women to have very independent ideas.

Indeed, Master Sheng Yen encouraged women to be independent and to contribute to Buddhism, regardless of their sex. In his Xue fo zhi jin 學佛知津 ('Instructions on Studying Buddhism'), for instance, Sheng Yen remarks that the eight fundamental rules, in fact, act as a restraint for bhikșunis: they become dependent and subordinated to monks, when having to attend the monks' order for events such as the ordination and invitation ceremonies or the settlement of a samghāuaśeșa offence (Sheng Yen 2005 [1985],184). He also expresses doubts on the authenticity of the gurudharmas, for being opposed to the spirit of Buddhism, and for not being in accordance with the standard way of establishing rules (p. 186). However, despite his doubts about the origins of the gurudharmas, he does not wish to abolish them, but rather advocates to not over-emphasize the rules, in order not to hinder bhikșunis' potential abilities and development $(2005,186-$ 187). His position became standard in DDM, which is not unusual in Taiwan where monastic institutional leaders are known to influence their disciples greatly, both in Buddhist theory and in practice. As aptly put by Wang Xiaochao $(2007,175)$, religious organizations generally revere their founders or leaders, whose words, deeds and writings often become the basis for institutional norms and systems. Individual and institutional charisma thus naturally merge..$^{50}$

50. On charisma of Buddhist institutional leaders, see, in particular, Kawanami 2009, 212-213. 
Another significant point made by the nuns I interviewed, is that 'there is no gender difference in Chan Buddhism'. This positive attitude of Chan Buddhism towards women is also defended by Shih Heng-Ching, a leading Taiwanese Buddhist nun and professor emeritus in the Philosophy department of National Taiwan University, who comments that the Chinese Chan school rates women's status and spiritual capacities highly, compared to other schools of Chinese Buddhism (Heng-Ching 1995, 132). Referring to one of the fundamental doctrines of the Chan school that says that all living beings have the Buddha-nature, she argues that the core of Chan teaching is that 'the innately pure nature of enlightenment possessed by all sentient beings ... transcends all dualities and distinguishing characteristics ..., including maleness and femaleness' (1992, 184). She further states that the monk Bodhidharma, traditionally seen as the first Chinese Chan patriarch, treated his male and female disciples equally $(1995,134)$. The fact that numerous biographies of Chan nuns have been compiled ${ }^{51}$ and that Chan documents record how nuns were involved in debates, even with monks, provides, according to Heng-Ching, still more evidence that the Chan school sees women's knowledge and spiritual enlightenment as equal to that of monks $(1995,136)$. To sum up, she concludes $(1992,183)$ :

The Ch'an School belongs to the tradition of 'Tathagatagarbha' thought, which advocates the universal enlightenment and the transcendence of differences in the realm of hsiang or external characteristics. No wonder that it is in the Ch'an School that Chinese Buddhist nuns received more recognition and respect than in any other schools. This positive attitude toward women is definitely related to the doctrines on which the Ch'an school is based.

When discussing the eight gurudharmas in the context of Chan Buddhism, HengChing $(1995,137-141)$ refers to the story of a famous ninth-century bhikșuni Chan master, Liaoran 了然, whose biography has been recorded in the Jingde chuan deng lu景德傳燈錄 ('The Transmission of the Lamp of the Jingde Era' (1004-1007)), compiled by the monk Daoyuan..$^{22}$ Her story shows how, while several gurudharmas were being disregarded, she was able to inspire the monk Guanxi Zhixian ( $d$. 895) towards enlightenment:

When the monk Kuan-ch'i Chih-hsien [pinyin Guanxi Zhixian] was travelling from place to place [looking for a teacher] he came to Mo-Shan. Before [meeting Liaojan [pinyin Liaoran], the abbess of Mo-shan], he said [to himself] 'If this place is all right, then I will stay. If not, then I will overturn the Ch'an platform (that is, show up the ignorance of the teacher).' So saying, he entered the hall. Liao-jan sent an attendant nun to ask: 'Are you merely sightseeing, or did you come for the Buddha Dharma?' Chih-hsien replied: 'For the Buddha Dharma.' Liao-jan then ascended to her seat. Chih-hsien asked for instruction. Liao-jan asked: 'Where did you start your journey today?' Chih-hsien replied: 'From the entrance to the road (lit., from the mouth of the road).' Liao-jan said: 'Why didn't you cover it?' Chihhsien had no reply. He then for the first time performed a kneeling bow. He asked: 'What is Mo-shan (lit., summit mountain)?' Liao-jan said: 'Its peak is not exposed.'

51. See Heng-Ching 1992, 183-184.

52. This story has been discussed equally by, among others, Levering (1982, 27-30) and Grant (2009, 14-15).

\section{eevinoxonline}


Chih-hsien said: 'What is the occupant of Mo-shan like?' Liao-jan replied: '(s)he has neither male nor female form (hsiang).' Chih-hsien shouted: 'Why doesn't she transform herself?' Liao-jan replied: 'She is not a spirit, nor a ghost. What would you have her become?' Chih-hsien at this could only submit. He became a gardener at the nunnery, where he stayed for three years. ${ }^{53}$

Heng-Ching (1992, 186 and 1995, 139) notes how Guanxi Zhixian introduced two major innovations that, in fact, go against the gurudharmas: First, as a monk, he knelt before the nun Liaoran when he felt challenged because he had nothing to say in reply; secondly, despite the fact that, according to the gurudharmas, Buddhist nuns are required to seek instruction from monks, Guanxi Zhixian nevertheless sought instruction from a nun.

In conclusion, we can see that more than just 'laissez-faire', the monastics of Dharma Drum Mountain have developed a clear position on the gurudharmas: not emphazising these rules is congruous with the position of the monastery's founder, seen as a leading guideline. Also, Chan Buddhism and its viewpoints on gender are put forward as an essential background for gender equality. And finally, the Taiwanese open social context is considered to have contributed to make these principles naturally acceptable.

\section{Nanlin Nunnery}

Nanlin Nunnery was founded in 1982 . There are about 70 resident nuns. Its name 'Nanlin' 南林, Southern Grove, is highly symbolic. It is taken from the name of the monastery where, according to the Biqiuni zhuan 比丘尼傳 ('Biographies of Nuns', $\mathrm{T}$ 2063), a compilation of biographies of Buddhist nuns traditionally attributed to the monk Baochang (ca. 466-?), ${ }^{54}$ a second ordination ceremony for Chinese nuns was held in c. 433 (T 2063 939c21-24): more than three hundred women received full ordination from a dual samgha with the help of a quorum of Sinhalese nuns. ${ }^{55}$ The name immediately shows how Nanlin Nunnery wants to be part of a development relating back to India and to the first dual ordinations of medieval China. It also demonstrates its reliance on a strict observance of the vinaya. As already noted by Li Yu-Chen, numerous young nuns regard Nanlin Nunnery's strict training and ascetic lifestyle highly, seen as a 'symbolic revitalization of the bhikșuni vinaya' $(2000,153) .{ }^{56}$ As a strongly vinaya-based nunnery, well known for its rigorous interpretation of monastic rules, Nanlin Nunnery clearly echoes DeVido's category of a 'strict observance of the [Eight] Rules.'

53. Translation of T 2076 289a1-9 by Levering 1992, 27-28.

54. For a translation, see Tsai 1994; for a study, see Georgieva 2000. According to Tom De Rauw (2005, 215-218), Baochang has, in all likelihood, been wrongly identified as the author of the Biqiuni zhuan.

55. On this so-called 'second ordination ceremony' for Chinese nuns and its reception in medieval China, see, among others, Heirman 2010. The second ordination ceremony was - in contrast to the first ordinations in the fourth century that were held in the presence of monk witnesses only - organized in the presence of nun witnesses too (a quorum of Sinhalese nuns), thus introducing a dual ordination ceremony in China.

56. Li Yu-Chen $(2003,518)$ also notes how some Buddhist circles in Taiwan are, in recent times, focusing more and more on the ordination procedure as promoted by some monastic institutes that strictly observe the precepts, such as Nanlin nunnery. 
Indeed, Nanlin nuns follow the eight fundamental rules strictly, including the instructions on poșadha (6), pravāraña (8) and summer retreat (7 - varșā) as laid down in the gurudharmas. As a lay woman, it is a pity that I (Tzu-lung Chiu) cannot participate in the relevant ceremonies to see exactly how vinaya legal procedures are carried out. However, from my interviews, from a monastic booklet and from a video, ${ }^{57}$ we can conclude that, as far as possible, Nanlin Nunnery strives to organize monastic activities in the way they are prescribed in the vinaya. For the poșadha, this implies that every fortnight, on the day of the ceremony, a nun (who needs to be accompanied by another nun) is assigned to go to the monk's order for instruction..$^{58}$ On the same day, before the start of the actual posadha ceremony, a repentance ritual is organized, which enables each nun to reflect on whether or not her behaviour is pure, a condition for participation..$^{59}$ Bhikșunis first recite the bhikșuni precepts, followed by the bodhisattva precepts (the latter being a Chinese Mahāyāna feature). Unordained women must still recite the śikșamānāa (probationer), śrāmanerī (novice) or upāsikā (lay woman) precepts, depending on their status in the nunnery. The day after poșadha, the nuns that had been assigned to go to the bhikșusamgha convey the instructor's message.$^{60}$ Furthermore, every year on the $15^{\text {th }}$ of April, Buddhist nuns proclaim their determination to hold the summer retreat, as described in the vinaya texts. On the last day, the invitation ceremony (pravāranāa) is held. A nun (accompanied by another nun) representing Nanlin Nunnery also goes to the bhikșusamgha for the pravārañ $\bar{a}$, in accordance with the gurudharma rules. Finally, following the end of the varșa period, the kathina ceremony is held, which marks the start of a period of donations by devoted lay followers. ${ }^{61}$ Lay attendants spread out a ceremonial kathina robe to check whether its design complies with the vinaya instructions.

Just like other monastic institutes, Nanlin Nunnery also has a key guiding master. In this case, it is the famous Vinaya Master Guang Hua (1924-1996), who is recognized as one of the most influential monks in Taiwan, promoting Buddhist monastics to practise vinaya rigorously. He inspired female followers to found Nanlin Nunnery. At the start of his well-known book, Jie xue qian tan 戒 學淺談 ('Basic Discussion on Vinaya'), Shih Guang Hua discusses the gurudharmas (2006,1-3). Referring to the Shanjian lü piposha 善見律毘婆沙, ${ }^{62}$ he reminds

57. The video introduces various ceremonies and practices of Nanlin Nunnery without showing all the formal acts, a lay audience not being entitled to participate in some of these.

58. When I stayed in Nanlin Nunnery, I noticed a public bulletin listing the fortnightly dates and the names of the nuns who were required to go for instruction to the monastery of Vinaya Master Guoqing (b. 1947). As a lecturer in various monasteries and nunneries, Master Guo qing is well known for his promotion of a strict interpretation of the vinaya.

59. According to the vinaya (T $1428825 \mathrm{c} 23-827 \mathrm{~b} 6$ ), one has to confess any offence before the start of the poșadha ceremony.

60. In the vinaya (see above), the instructor himself comes to the nunnery.

61. For details, see Heirman 2002, Part I, 221-226; Chung, 2004.

62. The Shanjian lü piposha (T 1462) is traditionally seen as a translation of the Samantapāsādikā, a fourth- or fifth-century Sinhalese commentary. The translation (completed in 488-489) is attributed to the monk Samghabhadra. Its relation to the Pāli text, however, is not that straightforward, and has been the topic of many debates. For details on this text and a discussion on its relationship to the Pāli Samantapāsādikā, see a recent study by Gudrun Pinte, Lost in Translation: A Case Study of Sanghabhadra's Shanjian lï piposha, Ph.D. Ghent University, 2011. Indeed, the Shanjian lï piposha states that a monk who, when instructing nuns, first teaches on

\section{eevinoxonline}


monks who have been asked by nuns to give them instruction, that they commit a duskrta if they do not teach the eight rules first before starting to lecture on the Buddhist Dharma. Furthermore, he stresses the importance of practising the eight rules by referring to the work of the famous Vinaya Master Daoxuan (596667), founder of the Nanshan lüzong 南山律宗, the 'Vinaya school of Nanshan'. This school promoted the Dharmaguptakavinaya, seen as the tradition on which the first Chinese ordinations were based..$^{63}$ Guang Hua $(2006,30-34)$ particularly points to Daoxuan's most influential commentary, the Sifen lü shanfan buque xingshi chao 四分律刪繁補閶行事鈔 ('An Abridged and Explanatory Commentary on the Dharmaguptakavinaya'), in which the importance of observing the gurudharmas is strongly underlined (T 1804 154c9-20). Daoxuan (p. 154c9-12) refers to a warning recorded in the Shanjian lü piposha, saying that, at first, the Buddha did not allow women to be ordained in the monastic community lest the Dharma would only last for 500 years instead of for 1000 years. ${ }^{64}$ Later on, he gave them permission, but only on condition that nuns follow the eight fundamental rules, which would permit the Dharma to last for 1000 years. ${ }^{65}$

Another key issue strongly emphasized by Master Guang Hua is the fact that, just as mentioned in the gurudharmas, each novice (śrämanerī) should receive the probationer (śikșamānāa) precepts two years before receiving full ordination as a bhiksuni ${ }^{66}$ If not, the full essence of the precepts cannot be grasped, even if one ordains as a bhiksuni $(2006,16-18,331-332)$. He adds, however, that the term śikșamāna is seldom heard of in Chinese Buddhism, where the śikșamānā period has, according to Master Guang Hua, never been applied. ${ }^{67}$ As a consequence, he says, Chinese nuns have obtained lesser results compared to the nuns of ancient India, and fewer will obtain enlightenment (332). ${ }^{68}$ In Nanlin Nunnery, however, all women have to go through the śikșamānā stage first before they can obtain full ordination as a nun.

The rigorous observance of the vinaya and its eight fundamental rules were also put forward by my interviewees. When I asked a senior nun, for instance, her view on the gurudharmas, she replied: 'The gurudharmas are indeed recorded in the vinayapitaka'. She also gave her view on academic interpretations of the gurudharmas:

There is no need for academics to discuss whether or not the gurudharmas have been edited by bhikșus after the demise of the Buddha, ${ }^{69}$ or to debate why the

the Dharma and only afterwards on the eight gurudharmas, commits a duṣkrta (T 1462, 799c5; translation in Bapat and Hirakawa 1970, 547).

63. Daoxuan, T 1804 51c7-9. See also T 2060 620c2-3.

64. On this prophecy, which is found in all canonical accounts of the founding of the order of nuns, see also Nattier 1991, 28-33; Heirman 2001, 278-284; Anālayo 2008, 106.

65. Corresponding to Shanjian lü piposha, T 1462 796c20-23.

66. In his classic book on vinaya, Jielü xue gangyao 戒律學綱要 ('Essentials of the Study of Buddhist Discipline'), Master Sheng Yen equally pleads for the introduction of a śikșamānā period in China (1997 [1965], 227).

67. It is indeed so that the śikșamānā period has never or only very rarely been implemented in China (see Heirman 2008), although Hao Chunwen in his work on daily monastic life in medieval Dunhuang does refer to some śikṣamānāa ordinations $(1998,36)$.

68. Also Sik Chien-yi, a nun of Nanlin Nunnery, stresses the importance of the sikșamānā stage in her work on Buddhist nuns (2002, xi-xii and 41-80).

69. Moreover, in 2007, at a conference on the (re)ordination of bhikșunis held in Hamburg, Oskar 
Buddha established these rules when there were no śikșamānās and so on. It is a problem of academics, since they fail to really understand the essentials and spirit of the gurudharmas. It is us, bhikșunis, who practise gurudharma after all.

The nuns' answers highlight the on-going debate on the usefulness of bringing academic research into a religious context. Indeed, as aptly put by Jens-Uwe Hartmann $(2010,25)$, 'to argue from an academic standpoint against a Buddhist view or vice versa may lead to a futile dispute between positions marked by either belief or rationality'. Still, Nanlin Nunnery itself, which specializes in researching vinaya, has also published numerous books ${ }^{70}$ and audio-tapes about Buddhist precepts for monks, nuns, probationers and novices. It is therefore not surprising that the nunnery follows the debate on the gurudharmas, though it might not accept certain implications defended by academics.

A second point emphasized by the senior nun is that only nuns are the real practitioners of the eight rules. Since academic people do not themselves observe these rules, they cannot grasp their deep inner meaning. It is indeed important for researchers always to reflect on insider/outsider issues that play a key role in religious study. During my fieldwork in Taiwan and Mainland China, I met several Buddhist nuns who were reluctant or unwilling to participate in interviews, especially on vinaya, because of my outsider identity. This concords well with Master Guang Hua's viewpoint on Buddhist vinaya as a practical exercise for Buddhist monastics, beyond the mere academic understanding of it $(2006,7)$. In other words, people can only truly understand vinaya when practising and experiencing it, which may remind us of a question raised by Russell McCutcheon (1999, 2): 'to what degree, if any, are the motives and meanings of human behaviors and beliefs accessible to the researcher who may not necessarily share these beliefs and who does not necessarily participate in these practices? ${ }^{71}$

When discussing the first rule of the gurudharmas, a rule which particularly attracted attention in both monastic and lay communities, the nun went on to say:

Gurudharma is an interactive relationship between monks and nuns. Paying homage is a way of showing respect but depends on a certain place, time and condition.

von Hinüber argued that the first nunneries only came into being (shortly) after the demise of the Buddha (also published in an article in 2008). To the monastic community, such a hypothesis is not at all attractive, be it only because it causes a breach in the direct link between the historical Buddha and the nuns' community. The idea has been discussed at length by Anālayo 2008, who puts forward numerous reasons why there are problems in von Hinüber's arguments, and who thus argues that it is highly improbable that the nuns' order could have come into being after the Buddha's demise. See also Heirman 2011, 622-623.

70. For more information, see http://www.nanlin.org/html/03/0102.asp (last access 14 June 2012).

71. The insider-outsider discussion on vinaya is at times linked to the idea that lay people should not be concerned with vinaya, a traditional viewpoint that can be found in a number of texts, such as, for instance: the Mūlasarvāstivādavinaya (T 1442 672c4-5: vinayapițaka is for monastic people, lay people should not hear it); the Fenbie gongde lun 分別功德論 (Treatise on Analysing Merit), a commentary on the Ekottarāgama, traditionally said to have been translated into Chinese in the Later Han (25-220 CE) dynasty (T 1507 32a14-15: vinayapitaka should not be heard or seen by novices or lay people); or the Da zhi du lun 大智度論, Mahāprajñāparamitāśāstra, attributed to Nāgārjuna and said to have been translated (or compiled) by Kumārajīva in the Later Qin (384-417) dynasty (cf. Paul Williams 1989, 74-75) (T 1509 66a12-13: vinayapitaka should not be heard by lay people).

\section{eevinoxonline}


We pay homage to pure and lawful monks by kneeling. Those lawful monks also respect nuns and do not sneer. However, we do not pay homage to monks expelled from the samgha and do not even join our palms to them. ${ }^{72}$

The nun indicates that Nanlin nuns kneel before monks. She emphasizes that (in accordance with the vinaya) they only pay homage to pure and lawful monks, in a relationship of respect. She adds:

Bhikșus are the senior Buddhist disciples among the seven categories of Buddhist followers. ${ }^{73}$ Therefore, we need to establish a respectful and appropriate relationship. When we oberve the rules, we do not feel inferior (emphasis given by the interviewee), because we run our nunnery independently. It is the academics' problem if they fail to really understand the essentials and spirit of gurudharma. We pay homage to monks and ask them for bi-monthly instruction. There is no problem of abuse (of the eight rules) if Buddhist monastics practise the rules legally. The gurudharmas are not in conflict with the Buddhist precepts we also observe.

In the above, the interviewee supports nuns' respect for monks on the basis of the idea of the overall seniority of the monks' order. She also strongly refutes any idea of inferiority, insisting on the fact that women can run a nunnery in an independent way, while still observing the gurudharmas.

In conclusion, we can say that Nanlin Nunnery, in common with other monastic institutions, equally often refers to one outstanding master. In this case, however, it is not the founding master, but a prominent vinaya teacher. Unlike DDM, the Nanlin interviewees do not refer to Chan Buddhism and its concepts of gender equality, but rather refer to Indian vinaya texts and the most influential early Chinese commentaries, notably by the famous vinaya master Daoxuan. The nunnery's strict observance of the vinaya rules attracts a growing number of young women in Taiwanese society. ${ }^{74}$ The nunnery insists on its insider position and qualifies the gurudharmas as a practice that can be understood by nuns only. The concept of inferiority is totally refuted. Instead, it is insisted upon that Nanlin Nunnery is run by nuns, independently, gurudharmas being seen as a sign of mutual respect between monks and nuns, in due awareness of seniority.

72. The Dharmaguptakavinaya (T1428 940a27-b5) mentions that monks that are expelled or need to be expelled should not be greeted by other monks. The Pāli vinaya is more explicit and stipulates (Vin II 262, and V 195) that nuns are allowed to stop greeting lewd monks who have acted disrespectfully towards nuns. The vinaya also indicates that such monks need to be punished by a dandakamma, which means something like 'thrashing' and generally refers to some (minor) punishment. In the case of a monk who is disrespectful to nuns, it consists of the nuns being allowed to stop greeting the guilty monk. See Hüsken 1997, 225-227; Nolot 1999, 69-74.

73. These are monks and nuns, probationers, male and female novices, and male and female lay followers.

74. A senior nun of Nanlin Nunnery explains why, according to her opinion, Nanlin Nunnery's monastic training and education may attract Taiwanese women: through a strict observance of the vinaya rules, Nanlin nuns want to closely connect to the Buddha's teachings. She especially points out the strict ordination procedures (novice, probationer, nun) and the focus on dignified behaviour in a single-sex monastery. 


\section{Luminary Nunnery}

Luminary Nunnery (also Luminary Buddhist Institute) was founded in 1980 by the nun Wu Yin (b. 1940). It currently has approximately 120 nuns and is famous for its teaching. Master Wu Yin, who is well known for her research on vinaya, runs a Buddhist college that provides education for nuns. Thanks are also due to Wu Yin's former master teacher, the nun Tianyi 天 乙 (1924-1980), who emphasized the importance of observing Buddhist precepts in Taiwan. ${ }^{75}$ Master Wu Yin is an experienced master, and has been teaching bhiksuni precepts at ordination events in various temples and countries. In her book (Choosing Simplicity, 2001) she explains, particularly to a western readership ${ }^{76}$ including bhikșunis, the Buddhist precepts and expresses her opinion about the gurudharmas (87-89):

While initially one could think that the eight gurudharma indicate that bhikshunis were seen as inferior, from another angle, one sees that the Buddha put responsibility on the bhikshus to aid and support the bhikshuni sangha. The bhikshus are not to ignore bhikshunis, but to help them to actualize the path. ...

In my thinking, having both men and women in the sangha made the situation more complex. ... the Buddha affirmed the bhikshus' leadership of the sangha in the gurudharma. For example, bhikshuni ordination is complete only after the new bhikshuni has come to the bhikshu sangha and received ordination from them as well as from the bhikshuni sangha.

In ancient times women were not well educated and lacked the skills to organize and educate themselves and to serve the society. The bhikshu sangha was also new and not well organized. On top of this, if another group - the bhikshuni sangha - was added, it could be difficult to sustain the Dharma. In fact, in the early days, bhikshus found it difficult to organize the bhikshuni sangha and to teach the nuns so many details. For this reason, the Buddha said if women join the sangha the true Dharma will be shortened by five hundred years. His main concern was not women's spiritual capabilities. Rather, he knew that, if the interrelationship between the two sanghas was not healthy, the Dharma would be the victim.

We have to know our opportunities and potentials, as well as our limitations. Understanding purity and impurity in guarding our precepts is also essential. Similarly, we must differentiate between the fundamental teachings of the Buddhadharma and cultural customs and taboos. Confusing cultural traditions with pratimoksha precepts leads to big problems. To be clear on all these issues, we must continuously study and discuss the teachings.

From the above, we can see that Wu Yin contextualizes the gurudharmas, referring (very similarly to what Chao-hwei has done before) to the lack of education of women in early India and the need for help from monks, urged by the Buddha to take upon them this responsibility. In this way, the Dharma was protected. When during my fieldwork in Luminary Nunnery, I personally asked Master Wu

75. Ven. Tianyi was especially influential ca. 1960-80 in Taiwan. She strongly promoted the independence and formal ordination of Buddhist nuns. For a detailed introduction of Tianyi, see Shi Jianye 1999.

76. Wu Yin's teachings to Western nuns are discussed by Yü Chün-fang (2010, 145-147).

\section{equinoxonline}


Yin for her opinion on the gurudharmas, she put forward two important points: first, gurudharmas are not to be seen as 'heavy precepts', and, secondly, they cannot be easily removed since they have been stipulated by the Buddha. After all, she said, the monks' order was established first. Still, she added that the gurudharmas might have been laid down by monks and she told me a story of the vinaya demonstrating how monks may have established some rules for particular circumstances. ${ }^{77}$ This does not imply, however, that the eight rules should be abolished, in contrast to what Chao-hwei advocates. Wu Yin says:

I disapprove of her abolishing the eight fundamental rules. They are impossible to be torn up. Moreover, she also invited lay people to participate in this event. Lay people do not need to observe the gurudharmas, so how could they be qualified to tear up these eight rules? The gurudharmas do not belong to lay people. So why does she let them destroy them? Shih Chao-hwei was swayed by her feelings and acted rashly by tearing up the eight rules together with lay people. I did not see her providing any supplementary measure later on.

Her statement again shows that Wu Yin does not plead for a removal of the eight gurudharmas. In addition, she particularly dislikes the fact that Shih Chao-hwei involved lay people in monastic affairs.

Just as in other places, the leader of the monastic community strongly influences his/her followers. This is also the case with Wu Yin. On the eight fundamental rules, a disciple of Wu Yin, sitting next to her, said:

Our teacher has taught us about the gurudharmas. We must observe them as laid down by the Buddha. But how do we practise these eight rules appropriately? We have our own way to interpret them. In my opinion, perhaps some bhikșus have edited the gurudharmas at that time [in ancient India]. We need to consider whether the implications of the gurudharmas still exist today. In ancient India the education of nuns was very limited, so they needed protection of the bhikșus, but today the situation is not like that. We cannot abolish the eight rules written down in the vinayapitaka stipulated by the Buddha. We still respect the ritual and the system (of the gurudharmas), but not per se all their specific contents.

The nun aptly expresses Wu Yin's teachings, emphasizing that the fundamental rules are not to be abolished, but need to be interpreted, taking into account the relevant context. She refers to the gurudharmas as a ritual rather than as a

77. Wu Yin relates how the Buddha told his attendants that he would like to concentrate on religious practice during the three months of the summer retreat. The monks then set up a rule that the Buddha should not be disturbed except for important matters. One day, a group of monks who had travelled from far away wanted to see the Buddha, but were told that they could not see him because of a rule that had been stipulated. The guest monks answered that they had never heard about the rule laid down by the Buddha's disciples. So, they argued, they should not be punished. This story is based on the Mahiśāsakavinaya (T 1421 26a9-b4, one visiting monk) and on the Mūlasarvāstivādavinaya ( $\mathrm{T} 1442$ 722b14-723a24, a group of visiting monks). Both vinayas develop a discussion on the validity of the resident monks' practice. Important in the above discussion on the gurudharmas, is that this story demonstrates that it is not impossible that monks could themselves lay down some rules. However, it should be noted that these rules are in fact merely local agreements, made within a particular monastic settlement. They need to be differentiated from rules that, according to tradition, originate with the Buddha and are laid down in the vinaya, thus becoming binding for all members of the Buddhist order. 
practice. A good example of what she means can be found in the way the rules on seeking instruction from monks and on holding the invitation ceremony are implemented: In her Ph.D. dissertation on Taiwanese nuns $(2000,146)$, Li Yu-chen indicates that the Vinaya Master Daohai (b. 1924), from the 1990s on, was chosen as a bhikșu instructor by many Taiwanese nunneries. She says that some nunneries began to ask for his instruction over the phone (rather than to have a personal meeting), but she does not give further explanations on why the mode of giving instruction changed. My fieldwork in Luminary Nunnery provides some more background. One nun told me that Master Wu Yin used to take some nuns to Daohai's monastery before each poșadha and at the pravārañā for instruction, in order to practise the monastic ceremony properly in accord with the vinaya regulations. ${ }^{78}$ The journey was quite long, so Master Daohai decided that it could be done by phone. A monk in Daohai's monastery was responsible for taking the nuns' call. A nun from Luminary Nunnery would call the monk, saying: 'Today we will recite the bhikșuniprātimokșa and we need your guidance'. The monk then put on his ceremonial robe, and the nun paid respect to him three times over the phone. At the same time, the monk may worship the Buddha. After that, the required ritual words were recited. Eventually, Master Daohai decided that some nunneries could manage their affairs independently and need not call for instruction. Nowadays, it is only during the summer retreat that Master Wu Yin always seeks instruction, in person and with student nuns, from Daohai's monastery. ${ }^{79}$

In fact, in Luminary Nunnery, on the one hand nuns seek to respect the vinaya, while, on the other hand, they seek to contextualize it in accordance with modern times in Taiwan. In that sense, the concept of gurudharma has developed into rather a ritual event..$^{80}$ The nun further commented:

We still respect gurudharma rather than just let it lapse, but as Buddhist nuns, we can handle some aspects of the eight fundamental rules by ourselves because modern bhikșunis with appropriate education can manage things independently. Some aspects of the eight rules we can handle by ourselves, with the Vinaya Master's (Daohai's) approval.

Another example also clearly illustrates how a careful balance is sought: Wu Yin's disciple told me about an incident that occurred in the nunnery's library, and is related to the first gurudharma rule (paying homage to monks). One day a monk came to the library for information. The monk saw a librarian nun and asked her to worship him by kneeling down. The librarian nun thereupon asked the monk to go to the Buddha Hall where she could formally receive him and pay homage. The monk, however, did not go to the Buddha Hall. Wu Yin further commented on this case:

Why should we, as Buddhist nuns, be like slaves, paying homage to monks just at any time and place? Did he have a problem that he needed a nun to pay homage in

78. In the early years of Luminary Nunnery, it was Master Guang Hua who had been chosen as an instructor (Yu 2010, 79).

79. This is confirmed in Wu Yin's Choosing Simplicity $(2001,82-83)$ : 'The bhikshunis at my monastery in Taiwan go to the bhikshu sangha for instruction during the summer retreat. At other times, we collect questions, and when a sufficient number have accumulated, we request bhikshus who are expert in certain areas of the Dharma or the Vinaya for answers or ideas. In addition, we study with other bhikshunis and professors of Buddhism'.

80. On ritualization of vinaya practices, see also Lopez 2001, 137.

\section{eevinoxonline}


the library (emphasis added by Wu Yin), because of his bhikșu status? The library is a place where librarian nuns work with their professional knowledge and Buddhist enthusiasm. Isn't it odd that the monk requested the librarian nun to worship just because he came into our library? The Buddhist vinaya is omnipresent. However, in this case, do we deal with the situation in accordance with vinaya or in accordance with commonly accepted social practices? If I am out in the (social) community as a bhikșunī I still need to queue up when I buy something in a shop or board a plane, following social regulations.

Her disciple added:

Our teacher has taught us that there is a proper order in Buddhism. This order follows different principles according to the situation. The (Buddhist) order is this: bhikșu, bhikșunī śrāmanera and śrāmanerī. However, sometimes the order is in accordance with seniority or monastic positions. For example, a rector (weinuo 維那) should stand in the appropriate place during a Buddhist ceremony in the Buddha Hall. As monastics, we need to consider the proper order commonly recognized in society when we are in the secular world. It does not mean that the monastics' position is higher. Society normally honours the elderly and the wise, and also follows the way of first come, first served. It is important to choose the appropriate order according to the situation. We cannot do whatever the vinaya or the eight rules require in this society. I do not think that the Buddha is insensitive (to this).

She continued:

If a bhikșu comes to our nunnery, we will respect him if he wishes to be respected by nuns, but if he is disrespectful towards us, we will avoid him. I also ignore those who have not yet reached a certain level of self-cultivation. We would always respect a monk visiting our nunnery. I am respectful towards you, am I not? I have no trouble respecting anyone I meet in accordance with the gurudharmas. However, we have our own way and style of showing respect.

Significant in the nuns' responses is the attention they pay to an appropriate balance and to the importance of practising Buddhism within secular society. Their sayings also clearly show a gender consciousness and a sense for empowerment. In conclusion, we can say that, just as in other monastic institutes, the founder of the institute is highly influential. In Luminary Nunnery, this is a woman, Master Wu Yin, herself having being trained by another famous female master, the nun Tianyi. The nunnery emphasizes that understanding the gurudharmas has to be realized in the monastic community itself, in a proper way, taking into account the relevant context. In that sense, a careful balance is being sought: while respecting the eight gurudharmas and applying them when circumstances seem appropriate, the social context of both the secular society of Taiwan and of present-day Buddhist nuns (who, in constrast to ancient Indian nuns, are very well educated) needs to be carefully taken into account. This implies that, in quite a lot of circumstances, the gurudharmas are not observed or have become of a more ritual nature. 


\section{CONCLUSION}

From the start of the bhikșunisamgha, gurudharmas have at times been a debated topic, and this continues to be the case in the present day, be it that in some Buddhist circles people prefer not to discuss it. In this article, we have first shown how the eight fundamental rules are an integrated part of the vinaya, and more particularly of the Dharmaguptakavinaya, that forms the basis of monastic ordinations in Taiwan. Against the background of a much debated attack on these gurudharmas by the nun Shih Chao-hwei, we have then analysed the viewpoints of contemporary Taiwanese nuns, focusing on some less studied, yet very influential, Taiwanese monastic institutes. This research has brought to light a diversity of opinions, that we should be careful not to categorize as ambivalent or even incongruous reactions to gender issues, but rather, as we have demonstrated, as well thought out standpoints, relying, in each case, on a clear vision on Buddhism and vinaya.

While Dharma Drum Mountain interviewees rely mostly on the teachings of Master Sheng Yen, founder of the monastery, Nanlin Nunnery nuns often refer to their vinaya teacher, the famous Vinaya Master Guang Hua. In Luminary Nunnery, it is again the founder who is most influentual, in this case a woman, Master $\mathrm{Wu}$ Yin. Dharma Drum Mountain nuns often emphasize gender equality as put forward in Chan Buddhism, and a feature they also see in Taiwanese society. In contrast, nuns of Nanlin Nunnery rely on traditional (Indian) vinaya texts and on early standard Chinese commentaries. Their strict observance of the vinaya rules attracts a growing number of Buddhist followers in Taiwan, including young women. They insist on an insider's viewpoint of monastic practitioners, refuting any idea of inferiority, and underlining due respect to seniors. Luminary Nunnery nuns take yet another angle. Here, interviewees attach a lot of importance to an appropriate contextualization of the vinaya and of the gurudharmas, taking into account contemporary Taiwanese society and the education level of present-day nuns. In doing so, they seek a balanced way to handle vinaya matters, and this strictly within the monastic community, in contrast to Shih Chao-hwei who opted for radical action involving lay people.

Although the three institutes show some similarities in that they all basically rely on the Dharmaguptakavinaya and respectfully promote the role of founders and teachers, our research has shown a large variety of responses to the gurudharmas in Taiwanese monastic Buddhism. Rather than seeking to reconcile all these opinions, it is important to see each of them within their own context and dynamics, or to rephrase a comment of Bhikkhu Anālayo in a study of early Buddhist discourses on women and nuns: such a 'multiplicity of voices', when being allowed to unfold, can tell us a lot about those who transmit them. ${ }^{81}$

\section{AKNOWLEDGEMENTS}

Our research has been supported by the Research Foundation Flanders (FWO). We would like to thank Peter Harvey and anonymous reviewers for their suggestions in improving the article. Any remaining shortcomings are our own.

81. Anālayo 2008, 142. See also Sponberg 1992, 3-4.

\section{eevinoxonline}




\section{ABBREVIATIONS}

T. Taishō Shinshū Daizōkyō 大正新修大藏經, J. Takakusu, K. Watanabe (eds.), Tōkyō

Vin The Vinaya Pitakam, H. Oldenberg (ed.), London, Pali Text Society

\section{BIBLIOGRAPHY}

Anālayo. 2008. 'Theories on the Foundation of the Nuns' Order - A Critical Evaluation'. Journal of the Centre for Buddhist Studies Sri Lanka 6: 105-142.

_. 2011. 'Mahāpajāpatī’s Going Forth in the Madhyama-ägama'. Journal of Buddhist Ethics 18: 268-317.

Carbonnel, Laure. 2009. 'On the Ambivalence of Female Monasticism in Theravāda Buddhism'. Asian Ethnology 68(2): 265-282.

Chao-hwei Shih 昭慧(釋). 1999. ‘Fojiao yu nüxing: jiegou fomen nanxing shawen zhuyi 佛教與女性. 一一解構佛門男性沙文主義' ('Buddhism and Women: Deconstructing Male Chauvinism in Buddhism'). In Lü xue jin quan 律學今詮 ('Contemporary Interpretation of Buddhist Discipline'), 335-388. Taipei: Fajie. . 2007. 'Theory and Practice of the Buddhist Feminist Movement in Taiwan: From Advocating Animal Rights to Female Rights'. In Religious Culture \& Gender Ethics, 2nd International Conference of Applied Ethics, edited by Shih Shing Guang, B1-B26. Kuan-yin: Hongshi Buddhist Cultural and Educational Foundation.

Chen, Chiung Hwang. 2011. 'Feminist Debate in Taiwan's Buddhism: The Issue of the Eight Garudhammas'. Journal of Feminist Scholarship 1: 16-32.

Cheng, Wei-Yi. 2007. Buddhist Nuns in Taiwan and Sri Lanka: A Critique of the Feminist Perspective. London: Routledge.

Chien-yi Sik 見一(釋). 2002. Han jia san pai: biqiuni zhong shou jie lunwenji 寒笳三拍比丘尼重受戒論文集 ('Three Chapters on the Refreshing Sound of the Dharma: The Collective Essays on the "Re-Ordination" of Nuns'). Nantou: Nanlin Press.

Chung, Jin-il. 1998. Die Pravāranāa in den kanonischen Vinaya-Texten der Mülasarvāstivādin und der Sarvāstivādin. Göttingen: Vandenhoeck \& Ruprecht. . 1999، 'Gurudharma und Aștau Gurudharmāh"’'. Indo-Iranian Journal 42: 227-234. 2004. 'Der Begriff kațina und die damit zusammenhängenden Termini - unter besonderer Berücksichtigung des *kälakalpa'. Annual of the Sanko Research Institute of the Studies of Buddhism 35: 1-17.

. 2006. 'Ursprung und Wandel der Aufnahme von Frauen in den buddhistischen Orden nach der kanonischen Überlieferung - eine Randbemerkung'. Annual of the Sanko Research Institute of the Studies of Buddhism 37: 1-16.

Chung, In Young 1999. 'A Buddhist View of Women: A Comparative Study of the Rules for Bhikșuniss and Bhikșus Based on the Chinese Prātimokșa'. Journal of Buddhist Ethics 6: 29-105.

Dantinne. Jean. 1991. Les qualités de l'ascète (Dhutaguna), Etude sémantique et doctrinale. Bruxelles: Editions Thanh-Long.

De Rauw, Tom. 2005. 'Baochang: Sixh-Century Biographer of Buddhist Monks ... and Nuns?' Journal of the American Oriental Society 125(2): 203-218.

DeVido, Elise Anne. 2004. 'The Infinite Worlds of Taiwan's Buddhist Nuns'. In Buddhist Women and Social Justice: Ideals, Challenges, and Achievements, ed. Karma Lekshe Tsomo, 219-231. Albany: State University of New York Press. . 2010. Taiwan's Buddhist Nuns. Albany: State University of New York Press. 
Dewaraja, Lorna. 1999. 'Buddhist Women in India and Precolonial Sri Lanka'. In Buddhist Women Across Cultures: Realizations, edited by Karma Lekshe Tsomo, 67-77. Albany: State University of New York Press.

Edgerton, Franklin. 1985 [reprint 1970]. Buddhist Hybrid Sanskrit Grammar and Dictionary, Volume II: Dictionary. Delhi: Motilal Banarsidass (first edition 1953, New Haven, CT: Yale University Press).

Georgieva, Valentina. 2000. Buddhist Nuns in China, from the Six Dynasties to the Tang. Ph.D. Dissertation Leiden University.

Goodwin, Allison. 2012. 'Right View, Red Rust, and White Bones: A Reexamination of Buddhist Teachings on Female Inferiority'. Journal of Buddhist Ethics 19: 198-343.

Grant, Beata. 2009. Eminent Nuns: Women Chan Masters of Seventeenth-Century China. Honolulu: University of Hawai'i Press.

Gross, Rita. 1993. Buddhism after Patriarchy: A Feminist History, Analysis, and Reconstruction of Buddhism. Albany: State University of New York Press. . 2005. 'Where Have We Been? Where Do We Need to Go?: Women's Studies and Gender in Religion and Feminist Theology'. In Gender, Religion and Diversity: Cross Cultural Perspectives, edited by Ursula King and Tina Beattie, 17-27. London: Continuum (first published 2004; first paperback 2005).

Guang Hua Shih 廣化(釋). 2006. Jiexue qian tan 戒學淺談 ('Basic Discussion on Vinaya'). Taichung: Nanputuo Buddhist Temple.

Hao, Chunwen 郝春文. 1998. Tang hou qi Wu dai Song chu Dunhuang sengni de shehui shenghuo 唐后期五代宋初敦惶僧尼的社会生活 ('Social Life of Dunhuang Monks and Nuns in the Late Tang, Five Dynasties and Early Song Period'). Beijing: Zhongguo shehui kexue.

Hartmann, Jens-Uwe. 2010. 'The Vinaya Between History and Modernity: Some General Reflections.' In Dignity \& Discipline: Reviving Full Ordination for Buddhist Nuns, edited by Thea Mohr and Jampa Tsedroen, 23-28. Boston, MA: Wisdom Publications.

Harvey, Peter. 2000. An Introduction to Buddhist Ethics. Cambridge: Cambridge University Press. http://dx.doi.org/10.1017/CBO9780511800801

Heirman, Ann. 1997. 'Some Remarks on the Rise of the Bhikșunisamgha and on the Ordination Ceremony for Bhikșunis according to the Dharmaguptaka Vinaya'. Journal of the International Association of Buddhist Studies 20(2): 33-85. . 1998. 'Gurudharma: an Important Vinaya Rule'. Indian Journal of Buddhist Studies 10(1-2): 18-26. . 1999. 'On Pārājika'. Buddhist Studies Review 16(1): 51-59. - 2001. 'Chinese Nuns and Their Ordination in Fifth Century China'. Journal of the International Association of Buddhist Studies 24(2): 275-304.

. 2002. The Discipline in Four Parts, Rules for Nuns According to the Dharmaguptakavinaya. 3 vols. Delhi: Motilal Banarsidass.

. 2008. 'Where is the Probationer in the Chinese Buddhist Nunneries?' Zeitschrift Der Deutschen Morgenlandischen Gesellschaft 158(1): 105-137.

. 2010. 'Fifth Century Chinese Nuns: An Exemplary Case'. Buddhist Studies Review 27(1): 61-76. http://dx.doi.org/10.1558/bsrv.v27i1.61 . 2011. 'Buddhist Nuns: Between Past and Present'. Numen 58: 603-631. http:// dx.doi.org/10.1163/156852711X593278

Heng-Ching Shih 恆清(釋). 1992. 'Chinese Bhiksunis in the Ch'an Tradition'. National Taiwan University Philosophical Review 15: 181-207. 
- 1995. Puti daoshang de shan nüren 菩提道上的善女人 ('Daughters of the Buddha on the Way to Enlightenment'). Taipei: Dongda Press.

von Hinüber, Oskar. 2008. 'The Foundation of the Bhikkhunisamgha, A Contribution to the Earliest History of Buddhism.' Annual Report of The International Research Institute for Advanced Buddhology at Soka University for the Academic Year 2007, vol. 11: 3-29.

Hirakawa, Akira. 1982. Monastic Discipline for the Buddhist Nuns - An English Translation of the Chinese Text of the Mahāsāmghika-Bhikșuni-Vinaya. Patna: Kashi Prasad Jayaswal Research Institute.

Horner, Isaline Blew. 1930. Women under Primitive Buddhism: Laywomen and Almswomen. New York: E. P. Dutton and Company.

Hsing Yun Shih. 2010. The Buddhist Perspective on Women's Rights (translated from Chinese by Tom Graham). Hacienda Heights: Buddha's Light Publishing.

Hüsken, Ute. 1993. 'Die Legende von der Einrichtung des buddhistischen Nonnenordens im Vinaya-Pițaka der Theravādin'. In Studien zur Indologie und Buddhismuskunde, Festgabe des Seminars für Indologie und Buddhismuskunde für Professor Dr. Heinz Bechert zum 60. Geburtstag am 26. Juni 1992, edited by Reinhold Grünendahl, JensUwe Hartmann and Petra Kieffer-Pülz, 151-170. Bonn: Indica et Tibetica Verlag. - 1997. Die Vorschriften für die buddhistische Nonnengemeinde im Vinaya-Pițaka der Theravādin. Berlin: Dietrich Reimer Verlag.

Jiang, Canteng 江燦騰. 2003. “Cong "sihui ba jingfa" dao "renjian fojiao sixiang” de chuanbo suyuan: youguan jinqi Taiwan renjian fojiao sixiang yu jielü biange de zhengbian wenti 從「撕毀八敬法」到「人間佛教思想」的傳播溯源 - 有關 近期台灣人間佛教思想與戒律變革的爭辯問題’ (“From “Tearing up the Eight Fundamental Rules" to "Humanistic Buddhist Thought”: A Recent Debate about Change in Taiwan Humanistic Buddhist Thought and Monastic Rules'). In Taiwan jindai fojiao de biange yu fansi: qu zhimin hua yu Taiwan fojiao zhuti xing queli de xin tansuo 台灣近代佛教的變革與反思：去殖民化與台灣佛教主體性確立的新 探索 ('Change and Reflection in Taiwan's Modern Buddhism: New Explorations in Decolonization and the Establishment of Taiwan's Buddhism Subjectivity'), 259-267. Taipei: Dongda Press.

Jianye Shi 見曄(釋). 1999. Zouguo Taiwan fojiao zhuanxingqi de biqiuni Shi Tianyi 走過台 灣佛教轉型期的比丘尼--釋天乙' ('Shi Tianyi: A Nun who Went Through the Transitional Period in Taiwanese Buddhism'). Taipei: Zhongtian Press.

Kawanami, Hiroko. 1990. 'The Religious Standing of Burmese Buddhist Nuns (thilá-shin): the Ten Precepts and Religious Respect Words'. The Journal of the International Association of Buddhist Studies 13(1): 17-39.

. 2009. 'Charisma, Power(s), and the Arahant Ideal in Burmese-Myanmar Buddhism'. Asian Ethnology 68(2): 211-237.

Kieffer-Pülz, Petra. 2005. 'Ehe- oder Lebensjahre? Die Altersangabe für eine "verheiratete” Frau (gihigatā) in den Rechtstexten der Theravādin'. Zeitschrift der Deutschen Morgenländischen Gesellschaft 155(1): 199-238.

Kusuma (bhikkhunī). 2000. 'Inaccuracies in Buddhist Women's History'. In Innovative Buddhist Women: Swimming Against the Stream, edited by Karma Lekshe Tsomo, 5-12. London: Curzon Press.

Laliberté, André. 2004. The Politics of Buddhist Organizations in Taiwan, 1989-2003:

Safeguarding the Faith, Building a Pure Land, Helping the Poor. London: RoutledgeCurzon. 
Levering, Miriam. 1982. 'The Dragon Girl and the Abbess of Mo-Shan: Gender and Status in the Ch'an Buddhist Tradition'. Journal of the International Association of Buddhist Studies 5(1): 19-36.

Li, Lingyu 李翎毓. 2005. 'You Taiwan fojiao biqiuni nüquan fazhan laikan “feichu ba jingfa yundong”由台灣佛教比丘尼女權發展來看「廢除八敬法運動」’(“A Study of "The Movement to Abolish the Eight Fundamental Rules" in Light of the Development of Taiwan's Buddhist Nuns' Feminism'). Master's Dissertation, Graduate Institute of Religious Studies, National Chengchi University, Taiwan.

Li, Yu-Chen. 2000. Crafting Women's Religious Experience in a Patrilineal Society: Taiwanese Buddhist Nuns in Action (1945-1999). Ph.D. Dissertation Cornell University. 一李玉珍. 2003. 'Fojiao de nüxing, nüxing de fojiao: jin ershinian lai zhongyingwen de fojiao funü yanjiu 佛教的女性, 女性的佛教一近二十年來中英文的佛 教婦女研究' ('Buddhist Women and Women's Buddhism: English and Chinese Research Works on Buddhist Women in the Past Twenty Years'). In Searching for the Paradigm: New Perspectives on Taiwan Religious Studies 台灣本土宗教研究的新 視野和新思維, edited by Hsun Chang and Tsann-terng Jiang, 489-524. Taipei: SMC Publishing.

. 2008. 'The Gender Issue in Contemporary Taiwan Buddhism'. In Buddhist Women in a Global Multicultural Community, edited by Karma Lekshe Tsomo, 189-199. Petaling Jaya: Sukhi Hotu Dhamma Publications.

Lin, Su-wen 林素玟. 2001. 'Renjian fojiao de nüxing guan-yi Xingyun dashi weizhu de kaocha 人間佛教的女性觀--以星雲大師為主的考察' ('Humanistic Buddhism’s Ideas on Women - A Study Focusing on Master Hsing Yun'). Universal Gate Buddhist Journal 普門學報 3: 228-271.

Lopez, Donald S. 2001. The Story of Buddhism. A Concise Guide to Its History \& Teachings. New York: HarperCollins Publishers.

McCutcheon, Russell T. 1999. 'General Introduction'. In The Insider/Outsider Problem in the Study of Religion: a Reader, edited by Russell T. McCutcheon, 1-11. London: Cassell.

Nattier, Jan. 1991. Once Upon a Future Time, Studies in a Buddhist Prophecy of Decline. Berkeley: Asian Humanities Press.

Nolot, Édith. 1991. Règles de discipline des nonnes bouddhistes, le bhikṣunivinaya de l'école Mahāsāṃghika-Lokottaravādin. Paris: Collège de France.

. 1999. 'Studies in Vinaya Technical Terms IV-X'. Journal of the Pali Text Society 25: 1-111.

Ohnuma, Reiko. 2006. 'Debt to the Mother: A Neglected Aspect of the Founding of the Buddhist Nuns' Order'. Journal of the American Academy of Religion 74(4): 861-901. http://dx.doi.org/10.1093/jaarel/lfl026

Owen, Lisa Battaglia. 1998. 'On Gendered Discourse and the Maintenance of Boundaries: A Feminist Analysis of the Bhikkhuni Order in Indian Buddhism'. Asian Journal of Women's Studies 4(3): 8-60.

Pinte, Gudrun. 2011. Lost in Translation: A Case Study of Sanghabhadra's Shanjian lü piposha. Ph.D. Dissertation Ghent University.

Salgado, Nirmala. 2008. 'Eight Revered Conditions: Ideological Complicity, Contemporary Reflections and Practical Realities'. Journal of Buddhist Ethics 15: 177-213.

Schak, David. 2008. 'Gender and Buddhism in Taiwan'. Hsuan Chuang Journal of Buddhist Studies 玄焋佛學研究 9: 145-174.

\section{eevinoxonline}


Schopen, Gregory. 2008. 'On Emptying Chamber Pots without Looking and the Urban Location of Buddhist Nunneries in Early India Again'. Journal Asiatique 296(2): 229-256. http://dx.doi.org/10.2143/JA.296.2.2036302

Seeger, Martin. 2009. 'The Changing Roles of Thai Buddhist Women: Obscuring Identities and Increasing Charisma'. Religion Compass 3/5: 806-822. http://dx.doi. org/10.1111/j.1749-8171.2009.00165.x

Sheng Yen Shih 聖嚴(釋). 1997 [1965]. Jielü xue gangyao 戒律學綱要 ('Essentials of the Study of Buddhist Discipline'). Kaohsiung: Foguang Cultural Enterprise Co. . 2005 [1985]. Xue fo zhi jin 學佛知津 ('Instructions on Studying Buddhism'). Taipei: Dharma Drum Publishing Corp.

Sponberg, Allan. 1992. 'Attitudes toward Women and the Feminine in Early Buddhism.' In Buddhism, Sexuality, and Gender, edited by José I. Cabezón, 3-36. Albany: State University of New York Press.

Su, Zhengguo 蘇正國. 2001. 'Xingyun: Foguangshan zao yi dongjie ba jing fa 星雲: 佛 光山早已凍結八敬法' ('Foguangshan Has Long Frozen the Eight Fundamental Rules). Zhongguo shibao 中國時報 (China Times), 1 April.

Tsai, Kathryn. 1994. Lives of the Nuns, Biographies of Chinese Buddhist Nuns from the Fourth to the Sixth Centuries. Honolulu: University of Hawai'i Press.

Tsomo, Karma Lekshe. 2004 'Is the Bhikṣunī Vinaya Sexist?' In Buddhist Women and Social Justice: Ideas, Challenges, and Achievements, edited by Karma Lekshe Tsomo, 45-72. Albany: State University of New York Press.

Waldschmidt, Ernst. 1926. Bruchstücke des Bhikșunī-Prātimokșa der Sarvāstivādins mit einer Darstellung der Überlieferung des Bhikșunī-Prātimokșa in den Verschiedenen Schulen. Leipzig: Deutsche Morgenländische Gesellschaft.

Wang, Xiaochao 王曉朝. 2007. Zongjiao xue jichu de shiwu tang ke 宗教學基礎的十五堂課 ('Religious Study Foundation'). Taipei: Wu-Nan Book Co.

Williams, Paul. 1989. Mahāyāna Buddhism. London and New York: Routledge.

Williams, Liz. 2000. 'A Whisper in the Silence: Nuns before Mahāpajāpatī?' Buddhist Studies Review 17(2): 167-173.

Wu Yin. 2001. Choosing Simplicity: Commentary on the Bhikshuni Pratimoksha (translated by Bhikshuni Jendy Shih; edited by Bhikshuni Thubten Chodron). New York: Snow Lion Publications.

Yü, Chün-fang 于君方. 2010. Xiangguang zhuangyan: Wu Yin fashi xingchuan香光莊嚴-悟 因法師行傳 (‘A Biography of Master Wu Yin'). Taipei: Ruoyu.

Yuan, Shipei 袁世珮. 2002. 'Fomen liang xing pingquan Xingyun biao zhichi 佛門兩性 平權星雲表支持 ('Master Hsing Yun Supports Gender Equality in Buddhism'). Lianhe bao 聯合報 (United Daily News), 21 April. 